\title{
副鼻腔炎による眼窩内合併症
}

\author{
- 32 症例の臨床的検討一
}

埼玉医科大学耳鼻咽喉科

金子研吾, 里和一仁, 久保田修,

飛田正, 三島陽人, 加瀬康弘

\section{Orbital Complication of Sinusitis}

\author{
Kengo Kaneko, Kazuhito Satowa, Osamu Kubota \\ Tadashi Hida, Haruto Mishima, Yasuhiro Kase
}

Department of Otolaryngorogy, Saitama Medical School, Saitama

\begin{abstract}
We present 32 cases of orbital complication caused by sinusitis. Clinical parameters such as age, gender, affected sinus, eye symptoms, and treatment were evaluated. Cases involved 25 males and 7 females with a mean age of 32 years ranging from 3 to 71 years. On the first visit, He subjects were seen in ophthalmology in 16 , internal medicine in 6 , and otolaryngology in 6 , and other in 4 . Ethmoid sinus was most frequently encountered. Presenting eye symptoms consisted of combination, such as ocular pain in 26, diplopia in 10, proptosis in 8 , and deterioration of visual acuity in 4 . Of these 20 were treated conservatively and 10 surgically. Hospitalization lasted 4 to 30 days (mean 12.2 days). CT and MRI were useful in diagnosis. Cases with visual disorders need immediate surgical intervention.
\end{abstract}

Key words : paranasal sinusitis, orbital complication

\section{はじめに}

眼窩と副鼻腔は隣接して存在し, 副鼻腔疾患により 種々の眼症状をきたすことは少なくない。眼症状は一般 に鼻症状より重篤であるため, 患者が耳鼻咽喉科を初診 するのはむしろ少なく, 眼科や内科等を経由して耳鼻咽 喉科に紹介されることが多い。このことは適切な診断お よび治療が遅れる原因のひとつになっている。従って結 果的に種々の重症度の眼合併症患者が突然に耳鼻咽喉科 に訪れることになる。

今回我々は副鼻腔炎による眼窩内合併症例の臨床検討 を行ったので代表的な症例をいくつか呈示し, 副鼻腔炎 による眼合併症例の対処法について, 若干の文献的考察 を加えて報告する。
対

対象は1994年 3 月から2003年 2 月までに埼玉医科大学 耳鼻咽喉科を受診した副鼻腔炎により眼窩内合併症を来 した 32 症例である。なお，囊胞などによる機械的な圧迫 や, 腫瘍に 2 次性に随伴する炎症が原因と考えられる眼 合併症は除外した。

\section{症例の呈示}

〔症例 1〕16歳, 男性

主訴：左㚘頁部痛, 左眼瞼腫脹

既往歴・家族歴：特記事項なし

現病歴：2002年 6 月 12 日より左㚘部痛が出現した。14日 より左眼瞼腫脹出現したため近医眼科受診。眼窩内合併 症が疑われたため，同日当科紹介となり，CT施行した ところ笁骨洞から波及した眼窩内炎症が疑われたため緊 


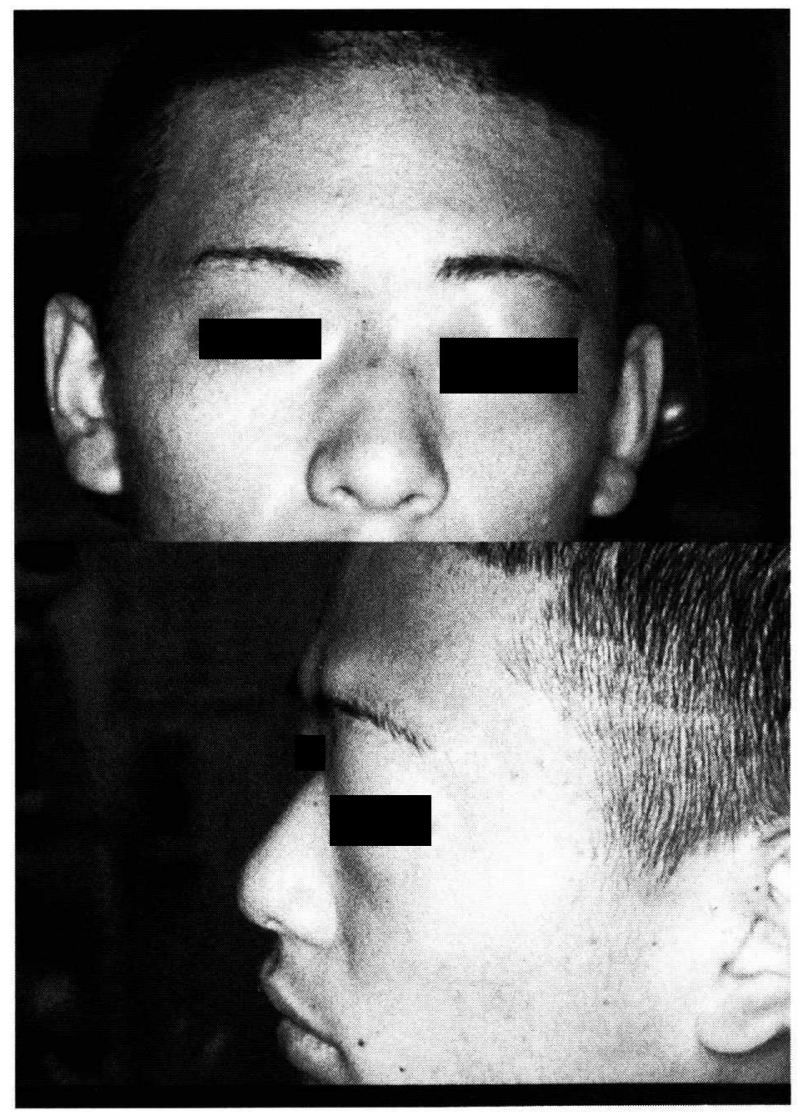

図 1 症例 1 : 入院時顔面写真

急入院となった。

初診時所見：左眼瞼腫脹，軽度発赤を認めた（図 1 )。 全周性に複視を認めたが，視力障害は認めなかった。鼻 内所見では左中鼻甲介腫脹し中鼻道より膿性鼻汁を認め た。

画像所見：CTにて篩骨洞炎および上顎洞炎を認め，左 側内直筋の軽度肥厚を認めた。（図 $2 \mathrm{~A}, \mathrm{~B})$ 。

臨床経過：画像所見より膿瘍形成を認めず, 眼窩蜂窩織 炎と診断し，PAPM/BP (カルベニン ${ }^{\mathbb{R}}$ ) $1.0 \mathrm{~g} /$ 日および CLDM (ダラシン $\mathrm{S}^{\mathrm{R}}$ ) $1.2 \mathrm{~g}$ /日の点滴静注を開始した。 鼻汁の細菌培養では黄色ブドウ球菌を認めた。その後, 複視，眼瞼腫脹徐々に改善し，6月28日退院となった。 〔症例 2〕19歳, 男性

主訴：右眼痛, 眼瞼腫脹

既往歴・家族歴：特記事項なし

現病歴：2001年 1 月 30 日より発熱, 頭痛, 鼻閉などの感 冒様症状が出現し，同月31日に右眼痛，眼瞼腫脹が出現 した。当院眼科受診し CTなどの結果，右急性副鼻腔炎 による眼窩内合併症の疑いにて同日当科紹介となり緊急 入院となった。

初診時所見：右眼瞼腫脹，発赤，眼球突出を認め, 全周 性に複視を認めた。視力障害は認めなかった。鼻内所見

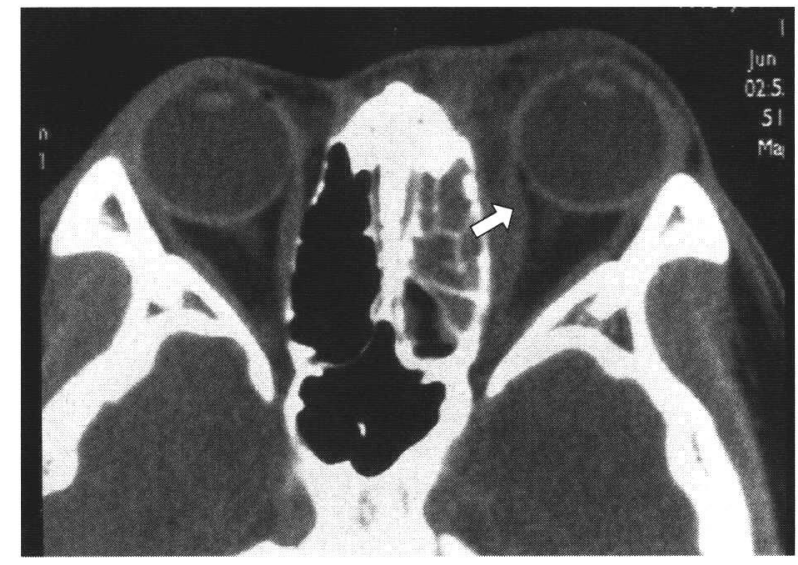

A

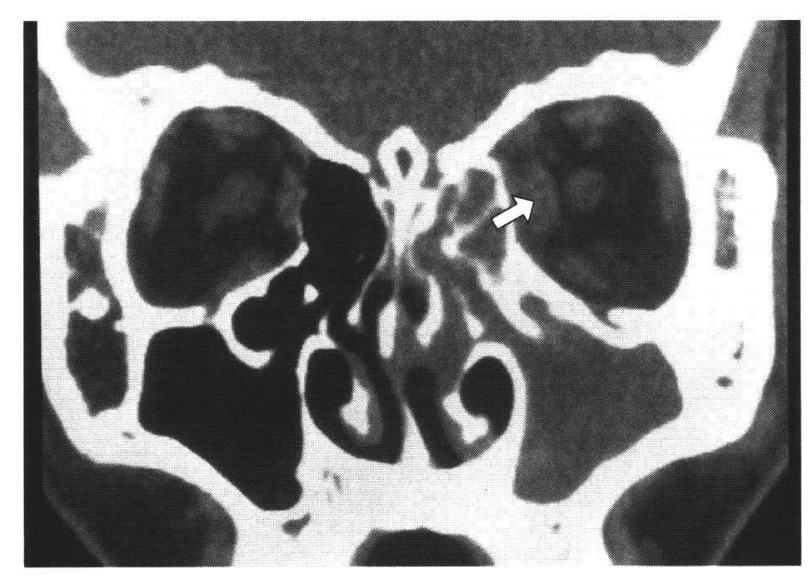

B

図2A 症例 1: 軸位断造影 CT 左側内直筋の反応性肥厚を認める（矢印） B 冠状断造影 CT 同様に篩骨洞から波及したと思われる炎症性肥厚 (矢印) を認める

では右中鼻甲介は浮腫状で中鼻道より膿性鼻汁を認め た。

画像所見：CTにて篩骨洞炎および上顎洞炎を認め, 冠 状断造影 CT にて右眼窩上部に辺縁に造影効果のある低 密度の楕円状陰影を認めた（図 $3 \mathrm{~A}, \mathrm{~B}$ )。

臨床経過：以上より眼窩骨膜下膿瘍と診断し, 2 月 1 日 緊急手術にて鼻外切開排膿ドレナージ，内視鏡下篩骨洞 根本術を施行した。採取した膿の細菌培養では Streptococcus intermediusを認めた。FMOX（フルマリンド) 2 . $0 \mathrm{~g} /$ 日および CLDM（ダラシン $\mathrm{S}^{\mathrm{R}}$ ) $1.2 \mathrm{~g} /$ 日の点滴投与 を開始。眼瞼腫脹消失し経過良好であったため 2 月 15 日 退院となった。

〔症例 3 〕 67歳, 女性。

主訴：右眼瞼腫脹，右視力低下。

既往歴・家族歴：特記事項なし。

現病歴：1999年11月 2 日より右眼瞼腫脹, 視力障害出現 したため, 近医眼科にて加療していたが, 改善しないた 


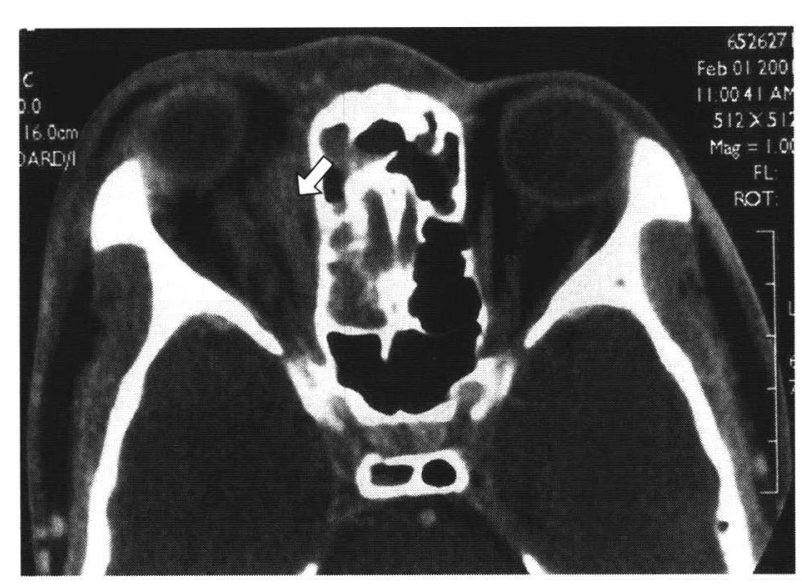

A

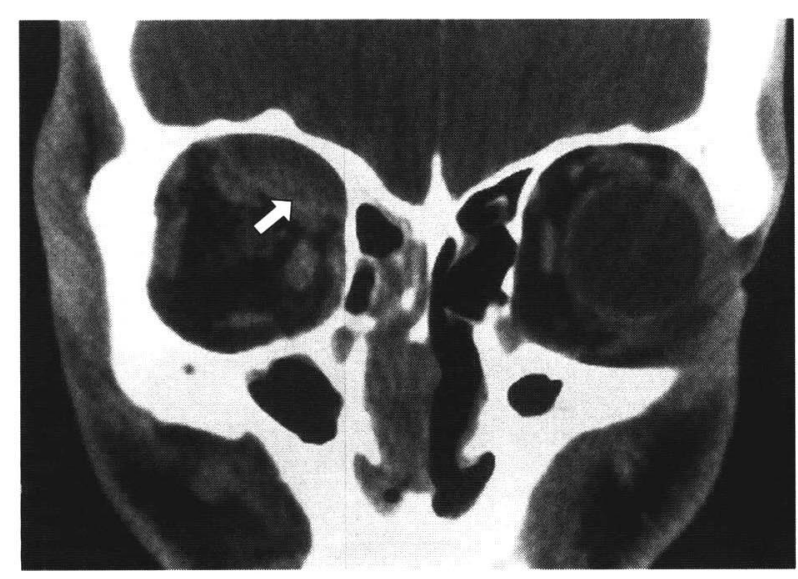

B

図 $3 A$ 症例 2: 軸位断造影 CT

B 冠状断造影 CT

右眼窩上部辺縁に造影効果のある低密度の楕円状 陰影（矢印）を認める。

め9 日近医耳鼻科受診。鼻鏡所見より副鼻腔炎の併発が 疑われたため, 同日当科紹介となり, CT 施行したとこ ろ前頭洞・篩骨洞から波及した眼窩内炎症を疑い緊急入 院となった。

初診時所見 : 右眼瞼腫脹, 軽度発赤, 眼球突出を認めた (図 4)。右視力は手動弁, 右眼底に網膜動脈分枝閉塞症 の所見を認めた。鼻内所見では右中鼻甲介は浮腫状で中 鼻道より膿性鼻汁を認めた。

画像所見：CTにて副鼻腔炎の所見と右眼窩内に膿瘍形 成を認めた（図 5 A，B）。

臨床経過 : 以上より眼窩内膿瘍と診断し, 視力低下を認 めることから入院同日, 緊急手術にて鼻外切開排膿ドレ ナージ, 内視鏡下篩骨洞根本術を施行した。採取した膿 の細菌培養では好気性菌, 嫌気性菌ともに陰性であっ た。術後, PAPM/BP(カルベニン $\left.{ }^{\circledR}\right) 1.0 \mathrm{~g} /$ 日および CLDM (ダラシン $\mathrm{S}^{\circledR}$ ) $1.2 \mathrm{~g} /$ 日の点滴投与およびプレドニゾロ ン $30 \mathrm{mg}$ より漸減開始。徐々に眼瞼腫脹低下してきた が, 視力は手動弁のままであった。視力障害以外の眼症

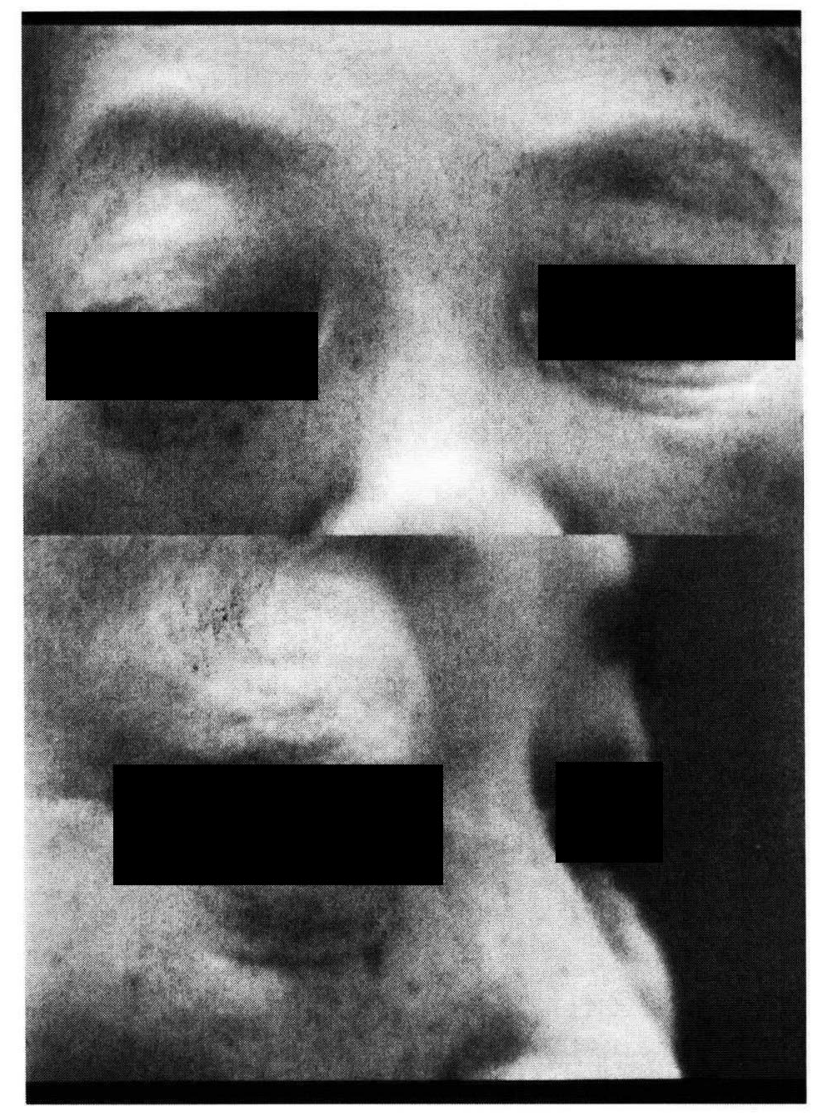

図 4 症例 3 : 入院時顔面写真

状消失したため11月22日退院となった。

\section{結果}

当科において入院治療を要した副鼻腔炎より眼窩内合 併症を来した, 自験例 32 症例のまとめを表 1 に示す。

1）年齢 - 性別

年齢は図 6 に示すように 9 歳以下が 2 例, 10 歳代が 11 例, 20 歳代が 5 例, 30 歳代が 5 例, 40 歳代が 1 例, 50 歳 代が 4 例, 60 歳代が 3 例, 70 歳代 1 例となった。平均年 齢32.3歳となり, 若年者に多く認めた。男性 25 例 $(78.1 \%)$ ，女性 7 例 $(21.9 \%)$ と男性に多く認めた。

2) 初診診療科

初診は眼科 16 例 $(50 \%)$, 耳鼻咽喉科 6 例 $(18.6 \%)$, 内科 6 例 $(18.6 \%)$, 皮膚科 2 例 $(6.25 \%)$, 整形外科 1 例, 脳外科 1 例となっており, 耳鼻咽喉科以外, 特に眼 科の初診が多かった（図 6)。

3）眻患副鼻腔

罹患副鼻腔は篩骨洞を含むものが32例 中31例 $(96.9 \%)$ ，上顎洞を含むものが23例 $(81.3 \%)$ で，次い で前頭洞 8 例 (34.4\%), 蝶形骨洞 3 例 $(12.5 \%)$ であ った（重複例含む）。なお上顎洞単独例は 1 例のみであ った（図 7 )。 


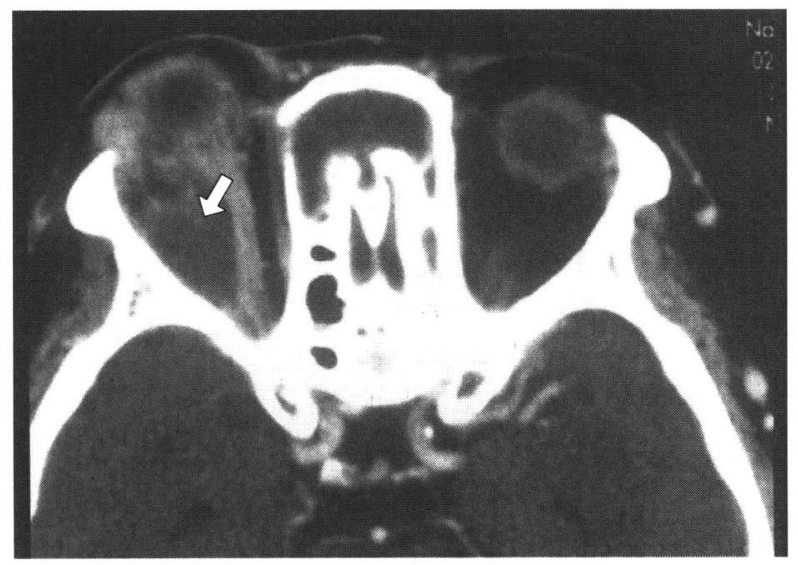

A

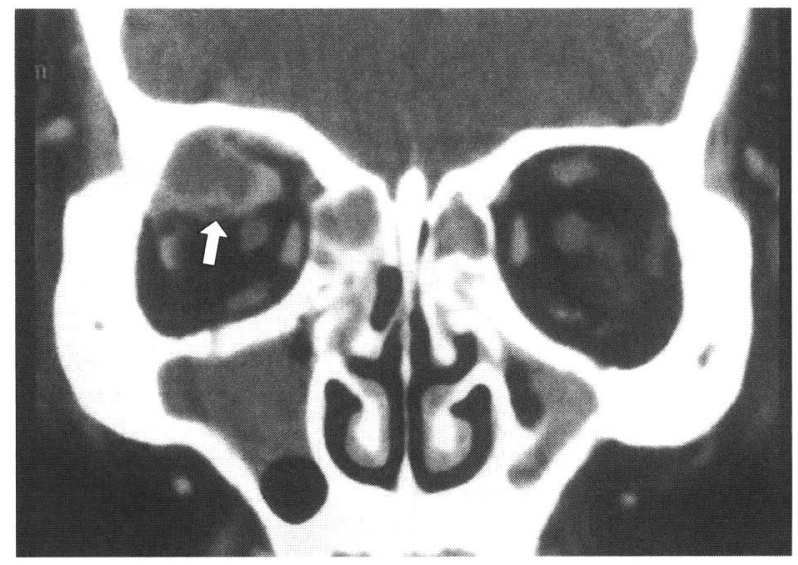

B

図 $5 A$ 症例 3: 軸位断造影 CT

右眼窩内に低密度の部分 (矢印) を認め, 視神経を圧排している。

B 冠状断贈位 CT

右眼窩内に低密度部分を認め膿瘍（矢印）を形成している。

表 1 当院における副鼻腔炎の眼窩内合併症例

\begin{tabular}{|c|c|c|c|c|c|c|c|c|c|}
\hline 症例 & 年鄐 & 性別 & 初繆科 & 䍜患副鼻腔 & 眼症状 & 治 療 & 細菌培養 & 分類 & 入院期間 \\
\hline 1 & 16 & $M$ & 眼科 & 上䭭、餙骨洞 & $\begin{array}{l}\text { 眼瞼腫脹、眼痛 } \\
\text { 複視 }\end{array}$ & 保存的治癔 & Staphyrococcus & 2 & 14日 \\
\hline 2 & 19 & $M$ & 眼科 & 上䫛、篩骨洞 & $\begin{array}{l}\text { 眼瞼腫脹、眼痛 } \\
\text { 眼球突出、複視 }\end{array}$ & $\begin{array}{l}\text { 鼻内管骨洞開放術 } \\
\text { 基外切開排腭術 }\end{array}$ & Streptococcus & 3 & 16日 \\
\hline 3 & 67 & $\mathrm{~F}$ & 眼科 & $\begin{array}{l}\text { 上顎、篩骨洞 } \\
\text { 前頭洞 }\end{array}$ & $\begin{array}{l}\text { 眼瞼腫脹、眼痛 } \\
\text { 視力障㮫 }\end{array}$ & 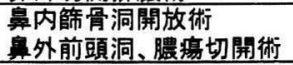 & 陰性 & 4 & 14日 \\
\hline 4 & 13 & $M$ & 眼科 & 上顎、管骨洞 & $\begin{array}{l}\text { 眼瞼腫脹、眼痛 } \\
\text { 眼球突出 }\end{array}$ & 保存的治療 & 陰性 & 1 & 15日 \\
\hline 5 & 10 & $M$ & 眼科 & 上顥、篣骨洞 & $\begin{array}{l}\text { 眼瞼腫脤、眼痛 } \\
\text { 眼球突出 }\end{array}$ & 保存的治療 & $(-)$ & 1 & 7日 \\
\hline 6 & 58 & $M$ & 眼科 & 篩骨洞 & $\begin{array}{l}\text { 眼瞼腫脹 } \\
\text { 眼球突出、複視 }\end{array}$ & 保存的治療 & $(-)$ & 2 & 17日 \\
\hline 7 & 15 & $\mathrm{M}$ & 眼科 & 篩骨洞 & $\begin{array}{l}\text { 眼瞼腫脹、眼痛 } \\
\text { 眼球突出、複視 } \\
\text { 視力低下 }\end{array}$ & $\begin{array}{l}\text { 上顎洞根本術 } \\
\text { 鼻外切開排膿術 }\end{array}$ & $\begin{array}{l}\beta \text {-streptococcus } \\
\text { Bacterides.f }\end{array}$ & 3 & 22日 \\
\hline 8 & 57 & $M$ & 内科 & 管骨、前頭洞 & 眼瞼腫脹 & 鼻内前頭節骨開放術 & 陰性 & 2 & 8日 \\
\hline 9 & 59 & $M$ & 眼科 & 笠骨洞 & 眼瞼腫脹、眼痛 & 保存的治療 & $(-)$ & 2 & 8日 \\
\hline 10 & 12 & $M$ & 耳基科 & 上䝷、笠骨洞 & 眼瞼腫脹、眼痛 & 上䝷洞洗浄 & Staphyrococcus & 2 & 13日 \\
\hline 11 & 19 & $F$ & 耳鼻科 & 上䫛、笁骨洞 & $\begin{array}{l}\text { 眼瞼腫脹、眼痛 } \\
\text { 複視 }\end{array}$ & 保存的治療 & $(-)$ & 1 & 4日 \\
\hline 12 & 36 & $M$ & 眼科 & $\begin{array}{l}\text { 上顥、笠骨洞 } \\
\text { 前頭洞 }\end{array}$ & $\begin{array}{l}\text { 眼瞼腫脹、眼痛 } \\
\text { 視力障害 }\end{array}$ & $\begin{array}{l}\text { 鼻内上䪽䇦骨開放術 } \\
\text { 鼻外前頭洞手術 }\end{array}$ & Streptococcus & 4 & 17日 \\
\hline 13 & 22 & $M$ & 眼科 & 上顎、篩骨洞 & 眼瞼腫脹、眼痛 & 保存的治療 & $(-)$ & 2 & 11日 \\
\hline 14 & 65 & $M$ & 整形外科 & 箁骨、前頭洞 & $\begin{array}{l}\text { 眼瞼腫脹、眼痛 } \\
\text { 複視 }\end{array}$ & $\begin{array}{l}\text { 㐭内穊骨洞開放術 } \\
\text { 鼻外前頭洞手術 }\end{array}$ & $(-)$ & 3 & 19日 \\
\hline 15 & 17 & $F$ & 眼科 & 笠骨洞 & $\begin{array}{l}\text { 眼瞼腫脹、眼痛 } \\
\text { 眼球突出、複視 }\end{array}$ & $\begin{array}{l}\text { 鼻内䇤骨洞汧放術 } \\
\text { 鼻外切開排膿術 }\end{array}$ & 陰性 & 3 & 30 日 \\
\hline 16 & 30 & $M$ & 内科 & $\begin{array}{l}\text { 上頼、笠骨洞 } \\
\text { 前頭、蝶形骨洞 }\end{array}$ & $\begin{array}{l}\text { 眼瞼腫脹、眼痛 } \\
\text { 眼球突出 }\end{array}$ & 保存的治療 & $(-)$ & 2 & 18日 \\
\hline 17 & 12 & $M$ & 眼科 & 上顎、節骨洞 & 眼瞼腫脹 & 保存的治療 & $(-)$ & 2 & 6日 \\
\hline 18 & 5 & $M$ & 眼科 & 汎副鼻腔炎 & 眼瞼腫脹、眼痛 & 保存的治療 & $(-)$ & 2 & 16日 \\
\hline 19 & 36 & $M$ & 眼科 & $\begin{array}{l}\text { 上顎、籂骨洞 } \\
\text { 前頭洞 }\end{array}$ & $\begin{array}{l}\text { 眼瞼腫脹、眼痛 } \\
\text { 眼球突出、複視 }\end{array}$ & $\begin{array}{l}\text { 鼻内餪骨洞開放術 } \\
\text { 悬外前頭洞、䐬楊切開術 }\end{array}$ & 陰性 & 3 & 17日 \\
\hline 20 & 3 & $M$ & 皮膚科 & 上顎、篩骨洞 & 眼瞼腫脹 & 保存的治療 & $(-)$ & 1 & 6日 \\
\hline 21 & 28 & $\mathrm{~F}$ & 耳鼻科 & 上顥、笠骨洞 & 眼瞼腫脹、眼痛 & 保存的治療 & $(-)$ & 1 & 10日 \\
\hline 22 & 21 & $M$ & 内科 & 上䫟、笠骨洞 & 眼瞼腫脹 & 保存的治療 & $(-)$ & 1 & 7日 \\
\hline 23 & 10 & $M$ & 耳鼻科 & 篰骨、蝶形骨洞 & 眼瞼腫脹、眼痛 & 保存的治癔 & 陰性 & 2 & 8 日 \\
\hline 24 & 28 & $M$ & 皮成科 & 上顎洞 & 眼瞼腫脹、眼痛 & 上顎洞洗浄 & $(-)$ & 1 & 14日 \\
\hline 25 & 48 & $\mathrm{~F}$ & 耳鼻科 & 篩骨洞 & 眼瞼腫脹、眼痛 & 鼻内穊骨洞開放術 & 陰性 & 2 & 24日 \\
\hline 26 & 18 & $M$ & 耳鼻科 & 上顎、節骨洞 & 眼瞼腫脹、眼痛 & 保存的治療 & $(-)$ & 1 & 7日 \\
\hline 27 & 30 & $M$ & 内科 & 上頻、笠骨洞 & 眼瞼腫脹、眼痛 & 保存的治療 & $(-)$ & 1 & 5日 \\
\hline 28 & 37 & $M$ & 内科 & $\begin{array}{l}\text { 上顎、篩骨洞 } \\
\text { 前頭洞 }\end{array}$ & $\begin{array}{l}\text { 眼瞼腫脹 } \\
\text { 前頭部痛 }\end{array}$ & 保存的治療 & Streptococcus & 1 & 4日 \\
\hline 29 & 51 & $\mathrm{~F}$ & 内科 & 上顎、篩骨洞 & 眼瞼腫脹、眼痛 & 保存的治療 & $(-)$ & 1 & 8日 \\
\hline 30 & 61 & $\mathrm{~F}$ & 眼科 & 笠骨洞 & 視力障害 & 鼻内箁骨洞開放術 & 陰性 & 2 & 6日 \\
\hline 31 & 71 & $M$ & 眼科 & $\begin{array}{l}\text { 上顎、笁骨洞 } \\
\text { 前頭洞 }\end{array}$ & $\begin{array}{l}\text { 眼瞼腫脹、眼痛 } \\
\text { 複視 }\end{array}$ & 保存的治療 & $(-)$ & 2 & 10日 \\
\hline 32 & 58 & $M$ & 脳外科 & $\begin{array}{l}\text { 上顎、篩骨洞 } \\
\text { 蝶形骨洞 }\end{array}$ & $\begin{array}{l}\text { 眼瞼腫脹、眼痛 } \\
\text { 複視 } \\
\end{array}$ & 保存的治療 & $(-)$ & 2 & 8日 \\
\hline
\end{tabular}




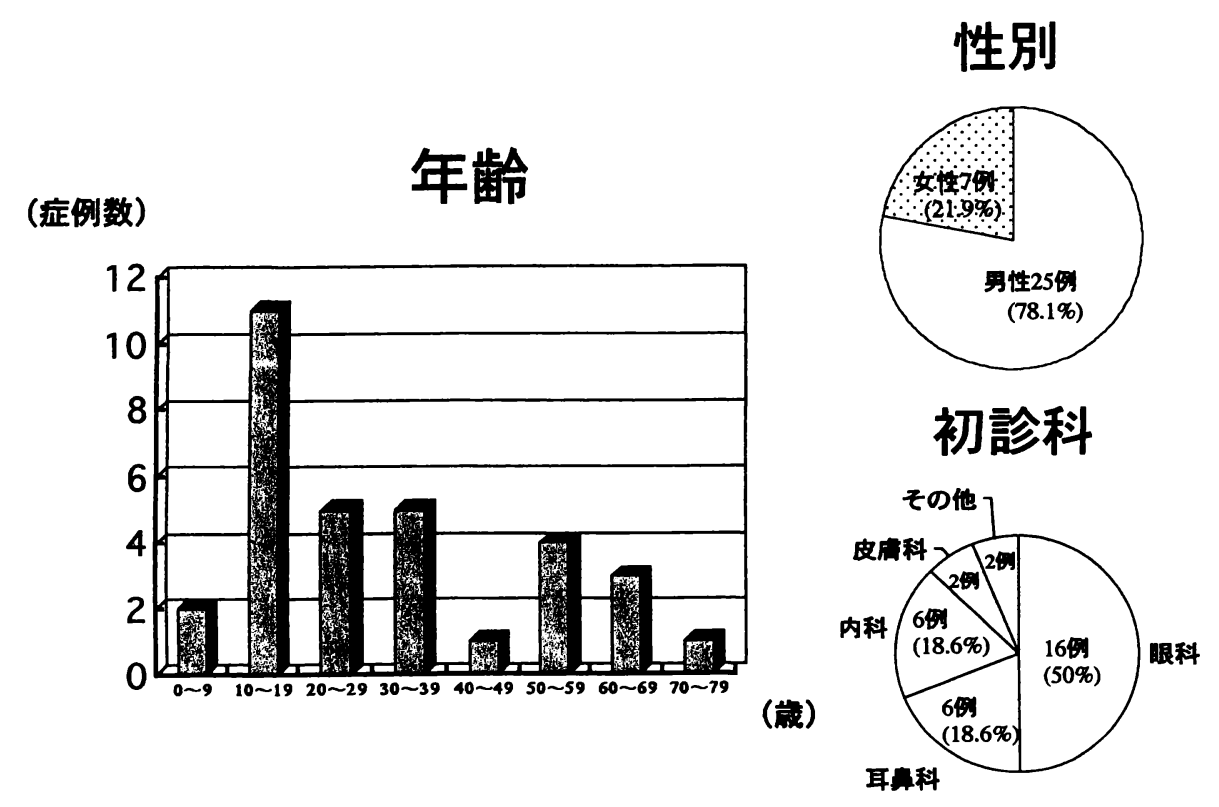

図 6 自験例 32 例の年齢・性別・初診科の内訳

\section{○罹患副鼻腔}

$\begin{array}{ll}\text { 笁骨洞 } & 31 \text { 例 }(96.9 \%) \\ \text { 上額洞 } & 26 \text { 例 }(81.3 \%) \\ \text { 前頭洞 } & 11 \text { 例 }(34.4 \%) \\ \text { 蝶形骨洞 } 4 \text { 例 }(12.5 \%)\end{array}$

\section{○眼症状}

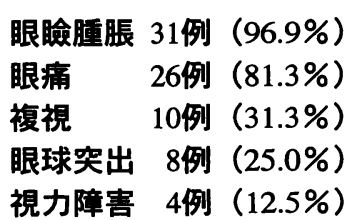

図 7 自験例の罹患副鼻腔・眼症状の割合

\section{4）眼症状}

眼症状では眼瞼腫脹をほぼ全例に認め, 眼痛が26例 $(81.3 \%)$, 複視を 10 例 $(31.3 \%)$, 眼球突出を 8 例 $(25 \%)$ に認めた。視力障害は 4 例 $(12.5 \%)$ に認めた（図 7 ）。

5）治療

今回検討した 32 例中，保存的治療は20例であった。 2 例には保存的治療に加え，上顎洞洗浄を施行した。外科 的治療は10例に施行したが，このうち 5 例では副鼻腔手 術に加え膿瘍の切開排膿術を併用した。

\section{6）細菌培養}

今回検討した 32 例中，細菌培養を施行した例が14症例 あり，陽性であった症例ではStreptococcal species 4 例，

S. aureus 2 例および Bacteroides fragilis 1 例を認めた。

\section{7）分類}

1970年 Chandler ら"は眼窩内炎症をその波及状態か ら 5 つのグループに分類した（図 8 ）。

Group 1 (眼瞼蜂巣織炎)：圧迫により篩骨動静脈の閉 鎖がおこり，上眼静脈の環流障害が生じた状態。

Group 2（眼窩蜂巣織炎）：眼窩内容のびまん性浮腫と 脂肪組織への浸潤があるが膿瘍の形成はない状態。
Group 3 (骨膜下膿瘍)：眼窩骨壁と骨膜の間に膿汁が 集積した状態。

Group 4（眼窩内膿瘍）：眼窩組織に膿汁の集積がみら れ，視力障害をきたすもの。

Group 5（海面静脈洞血栓症）：炎症が海面静脈洞にま で進展し反対側の眼球をも罹患した状態。

自験例 32 例についての内訳はGroup 1 が11例,

Group 2 が14例, Group 3 が 5 例, Group 4 が 2 例とな った。Group 1，2では25例中20例は保存的治療のみに て改善し，上顎洞洗浄を併用した例が 2 例，内視鏡下副 鼻腔手術を施行した例が 3 例であった。Group 4，5で は 7 例全例で手術療法を必要とした。

8）入院期間

入院期間は 4 〜 30 日で平均 12.2 日となった。

9）予後

眼瞼腫脹, 眼痛, 複視や眼球突出などの視力障害以外 の眼症状はいずれも治療開始後, 比較的早期に改善し た。視力障害については 4 例中 1 例において視力が回復 しない症例があった。

考察

眼窩と副鼻腔との間の解剖学的特徴として次のような ことがある。眼窩の鼻腔側壁は紙状板からなり，これは 非常に薄く，時には骨の間隙を形成しているので，鼻副 鼻腔疾患，特に篩骨洞病変が眼窩に波及しやすい。ま た，鼻副鼻腔からの血流は眼角静脈，上眼静脈を経て海 綿静脈洞，S 状静脈洞に至るが，逆流を防ぐ弁機構が欠 如しているので，菌が血行性に副鼻腔から眼窩に移行し 


\section{分 類}
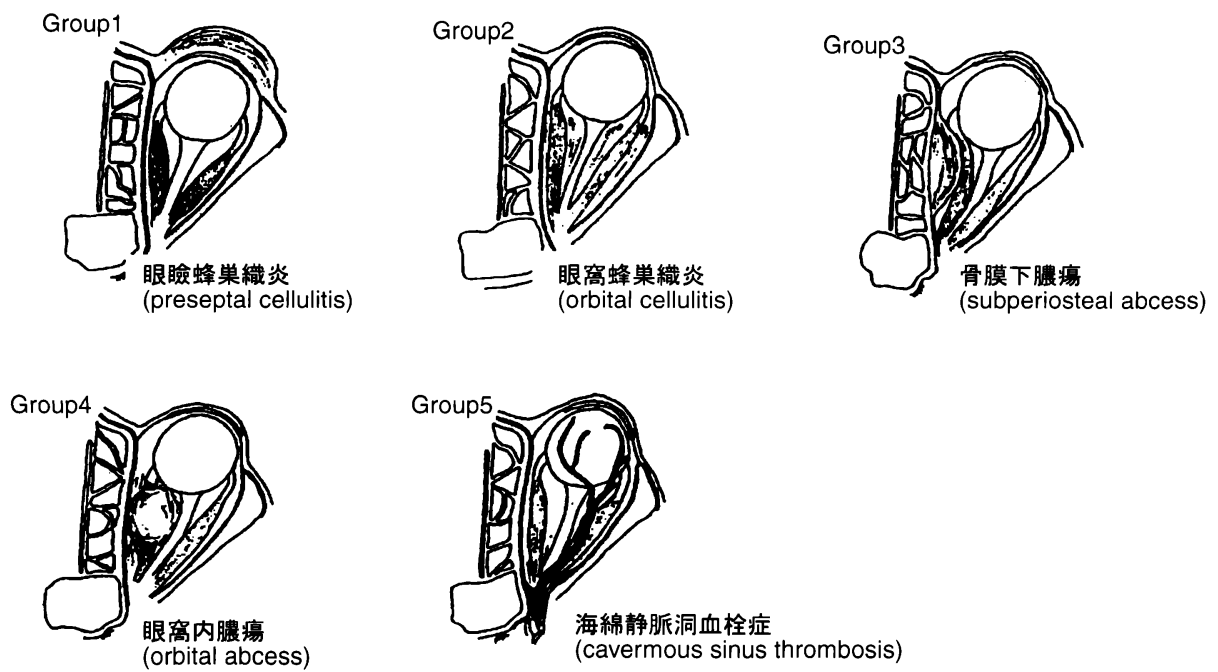

Chandler, 1970

図8 Chandler の分類

やすいといわれている。眼窩内炎症のうち鼻副鼻腔に起 因すると考えられるものの頻度は60～80\%とする報告が あり ${ }^{21}$, 一方副鼻腔炎から眼窩内合併症を起こす頻度は 3 〜 $\%$ と考えられている゙!。

以前我々が報告した 5 症例を含め4) 自験例 32 症例につ いて検討する。年齢は $0 \sim 9$ 歳 ( 2 例), 10〜 19歳（11 例）で平均年齢32.3歳となり，若年者に多く認めた。松 岡らは小児の場合, 篩骨眼窩板 (紙状板) の発育が不十 分であるため，炎症が紙状板を経て容易に眼窩に波及し やすいと述べている51。性比は本症例では25：7 で男性 に多いが，従来の報告においても同様に男性が多い傾向 である ${ }^{5.6)}$ 。

初診は眼科 16 例, 耳鼻咽喉科 6 例, 内科 6 例, その他 4 例となっており, 他科, 特に眼科の初診が多い。この 理由として多くの例で鼻症状より眼症状が目立って重篤 であることが挙げられる。また頭痛, 発熱や倦㤐感など の全身症状の強い例もあるので内科初診の頻度も高くな るのであろう。特に視力障害を来した場合早期に適切な 治療を施さないと自験例症例 3 のように回復しないケー スもあるため, 本疾患における眼科医との緊密な連絡は 必須である。

罹患副鼻腔は篩骨洞を含むものが32例中 31 例であっ た。しかし, 上顎洞単独の症例は 1 例のみであった。こ のことは上顎洞より眼窩内に炎症が波及することは稀 で，篩骨洞から紙状板を介して炎症が波及するケースが 多いと考えられる。過去に指摘される如く, 骨性, 血行
性いずれの感染経路おいても篩骨洞に炎症が及んだもの はその解剖学的な理由にて眼窩内へ波及しやすい5)。

眼症状では眼瞼腫脹をほぼ全例に認め，視力障害は 4 例に認めた。回復しなかった例は本報告症例 3 の 1 例の みであるが，当症例は視力障害が発症してから当科を受 診するまでにすでに 1 週間経過しており，来院時視力は 手動弁であった。緊急手術を施行したが，視力改善は認 めなかった。後部副鼻腔囊胞による視力障害について, 森山らは視力障害が重度のもの程予後が悪く，特に失明 ではその傾向は著明になると報告している7。また，発 症より手術までの期間が 1 力月以内であると改善率が良 く, 特に 2 週間以内のものに顕著であるという。本症例 は視力障害発症後，1週間で手術がなされているが，重 度の障害であったためか, 改善が得られなかった。蔦ら は視力低下発症より 2 日以内および光覚消失より 24 時間 以内の手術が予後を良好にする条件であると述べている が8), 重度の視力障害ほど, 可及的早期の手術が重要と 考える。

治療について, 1992年 Thomas らは視力障害が進行し た場合に手術適応になると述べているが91，上記理由に より視力障害を認めた場合は可及的早期に手術を行うの が好ましいと考える。視力障害のない場合では抗生物質 などの保存的治療を $24 \sim 48$ 時間施行し, 眼症状の改善が みられない場合は手術療法を考慮すべきである。敗血 症，髄膜炎，意識障害などの全身症状が出現した場合は 当然，積極的な手術適応となる。図 9 に当院での眼窩内 


\section{手術適応}

1. $24 \sim 48$ 時間の抗生物質投与で改善を認めない症例

\section{2. 視力障害を認める症例}

\section{3. 敗血症、葡膜炎などの全身症状か出現した症例 \\ 4. 輹瘍が証明され臨床症状を伴う症例}

図 9 当院における眼科内合併症の手術適応

表 2 副鼻腔炎合併症の起炎菌

\begin{tabular}{|c|c|}
\hline ○眼窩内合併症 & O前頭骨髄炎 \\
\hline ・小児 & Anerobic Streptococci \\
\hline H.influenzae & Staphylococci \\
\hline \multicolumn{2}{|l|}{ S.pneumoniae } \\
\hline ·成人 & O脳膿場 \\
\hline Streptococcal species & Staphylococcal species \\
\hline S.aureus & S.pneumoniae \\
\hline ·全般 & H.influenzae \\
\hline K.pneumoniae & Anerobes \\
\hline \multicolumn{2}{|l|}{ E.coli } \\
\hline P.aeruginosa & ○脳硬膜下膿瘍 \\
\hline Anerobes & $\begin{array}{l}\text { Streptococcal species } \\
\text { S.aureus }\end{array}$ \\
\hline ○餚膜炎 & Fusobacterium species \\
\hline S.aureus & Bacteroides fragilis \\
\hline S.pneumoniae & H.influenzae \\
\hline H.influenzae & Lactobacillus species \\
\hline \multicolumn{2}{|l|}{ Anerobes } \\
\hline & O海綿静脈洞血栓症 \\
\hline ○蝶形骨洞炎 & S.aureus \\
\hline \multicolumn{2}{|l|}{ S.aureus } \\
\hline \multicolumn{2}{|l|}{ Streptococcal species } \\
\hline \multicolumn{2}{|l|}{ H.influenzae } \\
\hline \multicolumn{2}{|l|}{ P.aeruginosa } \\
\hline \multicolumn{2}{|l|}{ K.pneumoniae } \\
\hline Enterobactor species & \\
\hline
\end{tabular}

合併症例の手術適応を示す。

表 2 にendall ら ${ }^{101}$ による副鼻腔炎の合併症とその起 炎菌を示す。眼窩内合併症では小児にインフルエンザ 菌, 肺炎球菌を多く認め, 成人には連鎖球菌群, 黄色ブ ドウ球菌を多く認める。その他, クレブシエラ, 大腸菌, 緑膿菌, 嫌気性菌群を認めることがある。今回検討した 32例中, 細菌培養が陽性であった症例は Streptococcal species 4 例, S. aureus 2 例および嫌気性菌 1 例が認め られたのみであった。これは 1 回の培養では原因菌が同 定できなかったり，化学療法にて陰性化してしまったた めと考えられる。抗生剂は FMOX (フルマリン ${ }^{\mathbb{E}}$ ) 13例, PAPM/BP (カルベニン ${ }^{\mathbb{E}}$ ) 12例, PIPC (ペントシリン ${ }^{\mathbb{}}$ ) 2 例，その他の抗生剤を 7 例に使用し，これに併用して CLDM（ダラシン $\mathrm{S}^{\circledR}$ ) を22例に投薬した。ステロイド を併用した症例は 5 例であり特に視力障害を合併した例
に多かった。抗生物質の選択は，まず広域スペクトルの 抗生剂を投与し髄膜炎への進展を考え髄膜移行性の優れ たものの使用が望ましい。また，嫌気性菌も考虑し可能 ならば二剤併用が望ましいと考える。

Chandlerの分類は篩骨を中心に眼窩への炎症の広が り状態を示している。今回呈示した症例 1 が group 2, 症例 2 が group 3, 症例 3 が group 4 に相当する。たと え眼瞼腫脹が軽度であっても眼窩に強く進展している場 合もあり，CT, MRI の画像診断が有効である。特に軸 位断 CT のみでは眼窩上壁に存在する膿瘍の存在が不明 確なこともあるため，上，内，下の 3 壁を同画面で診断 し得る冠状断層が有用である ${ }^{11}$ 。

入院期間は 4 〜 30 日で平均 12.2 日であったが, group 1，2では約 2〜3 日で眼症状が著明に改善する が，手術を要する group 3，4では入院期間が長期にな る傾向であった。

眼瞼腫脹, 眼痛, 複視や眼球突出などの視力障害以外 の眼症状はいずれも治療開始後，比較的早期に改善して おり予後は良い。一方，視力障害については 4 例中 1 例 において視力が回復しない症例があり，やはり早期発 見，早期治療が重要であると思われた。

$$
\text { まとめ }
$$

1. 副鼻腔炎による眼窩内合併症の 3 例を呈示し，自 験例32症例の臨床的検討を行った。

2. 若年男性に多く認め, 初診科は眼科が最も多かっ た。

3. 眻患副鼻腔は篩骨洞が最も多かった。

4. 視力障害を認めた場合，早期に手術を施行すべき と考え，手術適応について検討した。

5. 画像診断ではCT および MRI が膿瘍の診断に有 用であった。

\section{参考文献}

1 ) Chandler JR: The pathogenesis of orbital complications in acute sinusitis. Larygoscope 80:14141428, 1970.

2 ) Birch-Hirschfeld : Graete-Saemisch Hb. d. ges. Augenhegk $2^{\text {nd }}$ ed. Berlin 9: 471, 1930.

3 ）荒井秀一, 菊地康隆, 中島庸也, 他：副鼻腔由来に よる眼窩蜂窩織炎例。耳展 $31: 821-826,1988$.

4 ）金子研吾, 善浪弘善, 吉野 尚, 他：副鼻腔炎によ る眼窩内合併症. JOHNS 14：885-890, 1998.

5 ）松岡明裕, 設楽哲也, 八尾和雄, 他：小児急性副鼻 腔炎の臨床的検討. 耳鼻臨床 $86: 1425-1429$, 
1993.

6 ）佐久間 惇, 渡来潤次, 菊地原基敬, 他：副鼻腔炎 から眼窩蜂窩織炎をおこした小児の 4 症例。耳展 $31: 347-355,1988$.

7 ）森山 寛, 島田和哉, 斎藤 建, 他 : 後部副鼻腔震 腫. 耳展 $24: 465-480,1981$.

8 ）蔦 佳尚, 上川保廣, 友田幸一, 他：眼症状を呈し た副鼻腔囊胞の検討。耳鼻臨床 84：945-951, 1991.

9 ) Thomas MA, Chales MM: The Role of Computed Tomography in the Diagnosis of Subperiosteal Abscess of the Orbit. Clin Pediatr 31: 37-43, 1992.
10) Kendall K, Senders GW : Orbital and intracranial complication in children and adults. Diseases of sinusitis. Gershwin ME, Incaudo GA (ed), Humana press, Totowa, 1996, 247-271.

11）飯沼壽孝：難治性副鼻腔炎眼窩内合併症の治療耳 鼻臨床 $92 ： 688-689,1999$.

（2003年 3 月 2 日受稿, 2003 年 5 月 15 日受理） 別刷請求先：金子 研吾

干350-0495 埼玉県入間郡毛呂山町大字毛呂本郷38 埼玉医科大学耳鼻咽喉科

Tel : 049-276-1253 Fax : 049-295-8061 